\title{
The Financial Position of Youth Employee: Pinning-up of Financial Capability and Income
}

\author{
Ni Nyoman Sawitri ${ }^{1}$ and Agus Zainal Arifin ${ }^{2}$ \\ ${ }^{1}$ Fakultas Ekonomi dan Bisnis, Universitas Bhayangkara Jakarta Jaya \\ ${ }^{2}$ Fakultas Ekonomi dan Bisnis, Universitas Tarumanagara \\ Email Addres: \\ ninyoman.sawitri@gmail.com; agusz@fe.untar.ac.id
}

\begin{abstract}
The aim of the study on the financial behavior of youth employees is to review the impact of financial capability, income on financial behavior in evaluating the financial position. The main target of this study is mediating the evaluation of financial behavior in the effort of increasing the financial position of youth employees. A research method conducts with a survey of 100 youth employees in Indonesia, particularly in Central Jakarta, that has more youth employees. Data from youth employees obtain through questionnaires and data is processed by SmartPLS; remember that analysis technique is using the path analysis model. Research results found that financial capability and income have a truly significant impact on financial behavior; likewise, it is directly to financial position. However, it known that financial behavior cannot directly influence to financial position. Research novelty explains that financial behavior cannot be mediation between financial capability and income to financial position. This finding is useful for youth employees in understanding the financial position and for the government in comprehending the financial behavior of youth employees. So, it expects to be able to give the policy of financial management for youth employees.
\end{abstract}

Keywords: Financial Capability, Financial Behavior, Financial Position, Income.

\begin{abstract}
Abstrak: Tujuan dari penelitian pada perilaku keuangan pekerja muda adalah mengkaji dampak dari financial capability, income pada financial bihavior dalam mengevaluasi financial position. Sasaran utama dari penelitian adalah evaluasi mediasi dari financial behavior dalam upaya meningkatkan financial position dari pekerja muda. Metode penelitian dilakukan dengan survey pada 100 pekerja muda di Indonesia, tepatnya di DKI Jakarta yang memiliki lebih banyak pekerja muda. Data dari pekerja muda didapat melalui kuesioner dan data diolah memalui SmartPLS, mengingat teknik analisis dari model analisis jalur. Hasil penelitian ditemukan bahwa sejatinya financial capanility dan income memiliki dampak signifikan dengan financial behavior, begitu jua secara langsung pada financial position. Namun diketahui financial behavior secara langsung tidak mampu mempengarui financial position secara langsung. Novelty penelitian menjelaskan bahwa financial behavior tidak mampu menjadi mediasi antara financial capability dan income pada financial position. Temuan ini bermanfaat untuk pekerja muda dalam memahami financial position, juga pemerintah dalam memahami financial behavior pekerja muda. Sehingga diharapkan mampu memberikan kebijakan atas manajemen keuangan untuk pekerja muda.
\end{abstract}

Kata Kunci: Kapabiltas Keuangan, Perilaku Keuangan, Posisi Keuangan, Pendapatan. 


\section{INTRODUCTION}

Financial management is applied not only to companies but also to someone's personal as workforce (Holmes and Maghrebi, 2016). In this case, it relates to financial control in and out monthly for workers or people in business (Pedersen and Sudzina, 2012). The importance of financial management is related to someone's assets in the end (Totenhagen et al., 2019). There are not a few mistakes in financial management effects in unclear assets owned by someone (Wong et al., 2018). When it has entered the millennial era, or it is commonly known as management era 4.0 relates to the digitalization of every economic process and human life (Killip, 2013). The phenomena of the millennial age, an understanding of financial management is needed to be able to control financial position through assets owned. The millennial era filled now when it filled with youth employees because it enters the mid-life generation (Wang et al., 2015). It is important to notice because a youth employee tends to understand the theory of financial management. Still, the practice needs to be evaluated, especially in the millennial era where all of economic activity is not easy to be predicted (Chen and Lin, 2015). This evaluation is carried out to prepare youth employees when they were able to control to their financial position.

Financial position is a person's financial situation after it goes through several phases in financial management (Georgescu and Mates, 2017; Sawitri, 2019); it means that financial position requires time in its achievement. Many youth employees in Indonesia have better incomes currently (Indris and Primiana, 2015); however, it needs to evaluated within a period of one to three years from a financial position. It aims to provide opportunities for youth employees after they work for more than ten years, and it can provide a better financial position. Undoubtedly, financial position is a person's financial behavior (Levis et al., 2014; Sawitri et al., 2019), which means that the financial position can influence by financial behavior. It has been said before in a study of customer behavior that is related to financial behavior and financial position (Georgescu and Mates, 2017). This phenomenon explains the importance of studying financial behavior related to financial position. In financial behavior, it knowns as the financial capability that is related to the ability to manage someone's finances, both financial for themselves or company finances (Wilmarth, 2017). The previous studies have explained that financial capability provides a meaningful input for someone in financial behavior (Sawitri and Astuty, 2018; Xiao and Porto, 2016) so that financial practices are applied more efficiently and consistently. Financial capability is very closely related to education possessed by someone; in this case, it is a youth employee (Moreland, 2018). The higher the level of education, the better the actual behavior in financial capability. So that in some companies, it relates to finance, it is required for employees to have more knowledge of financial management (Totenhagen et al., 2019). It is sure to support personal self in behaving towards finances, and it also has a positive impact on its work as workers who understand financial management.

In companies, financial management is of great concern because finance in a company is a strong foundation for building a company, and finance is also very risky (Sydler et al., 2014). If it is not managed properly, it will be detrimental and will certainly stop a company from running (Yusoff and Adamu, 2016). In a company, it requires its own field that takes care of the financial department or it can be called financial management (Dwiastanti, 2017). Financial management is the activity of planning, managing, storing, and controlling funds and assets owned by a company. Financial management must be planned carefully so that 
problems do not arise in the future (Vithessonthi and Kumarasinghe, 2016). As with personal finance such as workers, it is necessary to carry out financial management to fit the financial plan (Laforet, 2007). This includes independent financial behavior that is managed by someone in their life (Singal, 2014). Financial management behavior deals with a person's financial responsibility regarding how to manage their finances (Yusoff and Adamu, 2016). Financial responsibility is the process of managing money and other assets in a way that is considered productive. Money management is the process of mastering using financial assets (Newberry, 2015). There are several elements that go into effective money management, such as budgeting, assessing the need for purchases and retirement debt within a reasonable period (Norden et al., 2014). The main task of money management is the budgeting process. The budget aims to ensure that individuals can manage financial obligations in a timely manner by using the income received in the same period (Dwiastanti, 2017). Each employee's experience in managing finances varies, such as in investment planning, savings, pension funds, insurance, and credit (Goedde-Menke et al., 2014). Experience is needed in managing finances for future survival. Employee experience is learning in managing finances so that they can make wise financial decisions, where the more individual experiences, the better they will make financial decisions (Godlewski, 2014).

Activities in managing finances include investing, saving, making credit, insuring and providing pension funds (Wong et al., 2018). Saving is part of financial management behavior by setting aside a portion of the total income earned (Arianti, 2017). Saving is the portion of income that is not spent or used for consumption. The rapid development of the era which is marked by the emergence of various luxury shopping centers such as shopping malls, various restaurants, and foreign brands, this can trigger consumptive activities (Moreland, 2018). Consumptive activities can hamper finances in terms of saving or saving (Shivam Dube and Kumar Asthana, 2017). Consumptive activities cannot be separated from the activities of human life with or without income (Arianti, 2017). This consumptive activity can be minimized by promoting savings just in case one day you need data quickly (Danilov et al., 2013). Apart from saving activities, it is possible for financial managers, including private employees, to make loans (Godlewski, 2014). For private employees who have other businesses, usually business funds do not come from their own funds because of the lack of capital they have, so many of them make credit or go into debt (Pi et al., 2012). Besides that, to fulfill a lifestyle according to the times, many have made loans such as vehicle loans, home loans, etc. In making credit, credit users must be more able to set aside monthly income to avoid defaults (Norden et al., 2014). A culture of high consumerism and almost all needs prices are increasingly soaring and without proper financial management it will burden individual employee finances (Szendrey and Fiala, 2018). If you have idle funds, you should set it aside to carry out investing activities whose goal is to generate returns. Types of investment are divided into two, namely investment in real assets and financial assets (Delis and Mylonidis, 2015).

In financial behavior, sometimes, other factors are outside of financial behavior, namely the amount of income or it is called income (Díaz Caro and Crespo Cebada, 2016). It has to know that for workers who are married or who are single, the amount of income significantly impacts to financial behavior (Wilmarth, 2017). The essence of this finding explains that financial behavior can be influenced not only from financial capability but also from the amount of income owned. Most of them have behavior; the greater of income, so 
the higher of needs (Haeussler and Sauermann, 2013). Relating to the action of financial, financial management is needed to be able to control financial behavior (Moreland, 2018). Examining the phenomenon of problems in youth employees in Indonesia, this study focuses on the study of financial capability, financial behavior, income, and financial position of youth employees. The survey conducts through testing to mediation model of financial behavior; it has never been done before, especially for youth employees in Indonesia. So, there is a map of current research that aims finally in the effort to build the financial position of youth employees in Indonesia.

\section{THEORETICAL REVIEW}

Financial Capability. The financial literacy of youth employees is influenced entirely by the level of education possessed (Totenhagen et al., 2019). However, along the way, life experience provides opportunities for the financial capability of youth employees (Wong et al., 2018). Because theory and practice that relate to financial management are very different. Someone very skilled in financial knowledge is not always very proficient in their practice in managing finances (Szendrey AND Fiala, 2018). It happens because the actual economic behavior depends on the experience they have. The real financial capability helps employees in managing finances earlier, with the aim that the amount of income is in line, and it is smaller than the amount of expenditure (Moreland, 2018). So, economic principles can be applied early. Financial capability is sometimes associated with someone's ability to regulate monetary policies (Košak et al., 2015), such as implementing the investments for future profits. However, the financial capability depends entirely on individuals in understanding financial management. The lack of a person's financial knowledge can cause financial problems (Gelman et al., 2015), where financial problems are not only a function of low income (Laforet, 2007), but can also occur due to mistakes in managing finances (Fauceglia, 2014), such as mistakes in crediting and lack of financial planning. If applied to the lives of private employees, financial errors can occur due to mistakes in managing monthly salaries such as mistakes in buying unnecessary items in the absence of financial planning beforehand (Arianti, 2017), so that the monthly salary runs out prematurely. Capability, which means the same as competence, namely Ability (Wong et al., 2018). However, the meaning of capability is not limited to having skills but more than that, namely understanding in more detail so that you really master the ability from the point of weakness to how to overcome it (Ramanathan et al., 2016). Capabilities are more specific skill sets, procedures, and processes that can leverage resources to a competitive advantage (Rai et al., 2019). Based on the definition of capabilities that have been disclosed, it can be defined as an ability that has more than just skills at something that is a competitive advantage and mastering abilities from weakness points (Armijo et al., 2014).

The previous studies said that financial capability is an individual's knowledge, skills, and confidence in financial management; its impact on financial management principles can improve the quality of financial decision making better (Henager and Cude, 2016). The study explained that financial capability contains three main things, which are knowledge, skills, and confidence in implementing financial principles in his life so that financial prosperity can achieve. Regarding financial behavior, there are several measurements commonly evaluated, namely the ability to handle financial problems, the ability to record monthly expenses, the ability to manage the costs no more than income, the ability to 
manage financial profits and the ability to prioritize the needs of financial intention (Henager and Cude, 2016). In principle, it knows that someone's financial capability has excellent opportunities for improvement of financial behavior (Wilmarth, 2017), and it has the opportunity to improve someone's financial position in the future (Moreland, 2018).

Income. Income is an employee's income, which is assessed based on financial value (Wilmarth, 2017); the greater income usually followed by a higher level of work performance and its impact. It means that income is influenced by how much activity is carried out by employees or businesspeople in their work. In theory, salary said to be real income from someone who use to fulfill their needs individually and with others (Moradi et al., 2016). The amount of income is usually followed by the number of requirements (Moreland, 2018), so that the greater of income, the more someone's expenses in fulfilling their needs. In the business world, the term income is familiar (Sawarjuwono, 2003). Income is income arising from company activities which is commonly known by different names such as sales, sales of services, interest, dividends, royalties and rents (Bretscher et al., 2016). Income is very important, because that income is the object of the company's activities (Shen et al., 2016). In Indonesia, there are quite several terms related to income (Dwiastanti, 2017). Examples are family income, community income, regional income, state income, and per capita income. Income is very influential on the continuity of a business (Xiao and Porto, 2016). The greater the income obtained, the greater the ability of the business to finance all expenses or daily operational costs that will be carried out (Gaganis and Pasiouras, 2013). Income is an element that must be done in doing a business because it could be that income is one measure of success (Lee et al., 2016). The definition of income varies, depending on which side we see the meaning.

In the theory of financial management, income is related to salary; it comes from the main job and side jobs from individuals who use to fulfill their needs as humans and their intention, which makes them more fun (Arianti, 2017). From this theory, it knows that income can provide happiness because the level of needs and the intention will be fulfilled. It is said more commonly that income is the gross salary of an individual in a matter of years, which he uses to fulfill his needs, both personal needs or business needs, such as investment (Kadoya and Khan, 2017). Nowadays, income is often associated with financial behavior (Arianti, 2017), because of its impact on financial behavior as well as on financial position, which value from assets owned. It means that someone's income needs to be accompanied by financial knowledge so that the impact of financial behavior and financial position will be better. Particularly for youth employees who are weaker than experience in financial management (Mirvis et al., 2014). In a previous study, it found that in assessing income, it could be known from several activities including activities to set aside income, businesses to follow a financial budget, businesses to face retirement, financial innovation activities and activities to manage the emergency funds (Xiao and Porto, 2016).

Financial Behavior. Financial behavior is a person's activity relates to decisions in finance, which leads to the value of assets owned by someone (Wilmarth, 2017). Financial behavior has a positive impact to financial position genuinely because financial behavior provides individual opportunities in making financial decisions following the economic principles (Bohl et al., 2014). However, it does not guarantee perfect because other factors are being able to control financial positions (Georgescu and Mates, 2017). In theory, it states that 
financial behavior as an individual's ability to manage finances following financial goals at the beginning as financial management every month (Kadoya and Khan, 2017). So that, it can be seen in its activities that financial behavior leads to three main things, are in terms of using funds, setting aside funds, and investing funds possessed by someone (Dwiastanti, 2017). Financial behavior truly depends on knowledge of someone's management, so financial behavior depends on someone's expertise in financial management in the long period.

The previous studies have identified the characteristics that measure financial behavior, includes planning activities, budgeting activities, inspection activities, management activities, control activities, searching activities, and storage activities (Hariyanto and Alamsyah, 2019; Kadoya and Khan, 2017). Through these indicators, it can know how far individuals implement financial principles through financial behavior. Someone who has worked, often to be wrong in practicing financial management, it dues to a lack of direct experience and the absence of an obligation considering that someone needs to implement the principles of financial management (Kenç et al., 2016). It usually happens to youth employees, although financial literacy is already functional, in its implementation, it is often inappropriate. So financial position is not in line with the expectations, which is the lack of ownership of assets (Pintea et al., 2014).

Financial Position. Another financial behavior attached to a person is financial position; it often said to be an asset owned by someone because it has gone through a process or time in financial management (Alamsyah et al., 2020; Georgescu and Mates, 2017). Financial position is a financial position, which is a picture of a company's financial condition as indicated by the value of the company's assets (assets) and debt as reflected in the company's balance sheet (Levis et al., 2014). The company's financial position (business financial position) is a description of the financial condition of a company (Shivam Dube \& Kumar Asthana, 2017). There are several elements that must be contained in a balance sheet, namely assets, liabilities, and equity (El-Khatib et al., 2015). Assets are sources that are useful for the business later. In theory, it said that financial position is a precondition for of an individual's finance who judge by the number of wealth and debt owned during this (Moreland, 2018). The theory explains that financial position provides an excellent opportunity for individual development in financial management to collect assets in the future. Concerning financial position, it is known several indicators that become measurements such as the condition of having assets, the ability to fulfil the primary needs, the ability to fulfil the secondary needs, the ability to pay bills, the ability to use assets, the ability to cut living costs and the ability to overcome financial problems (Kadoya and Khan, 2017). Some of these indicators often used as measurements, especially for customer behavior over financial management on their savings. However, in general, it can be used as a measurement in financial behavior to assess a person's financial position (Kenç et al., 2016).

Hypothesis Model. In a previous study, it found that financial capability has a relationship to financial behavior (Wilmarth, 2017), and also a relation to financial position directly (Moreland, 2018). Furthermore, it also is known that the amount of income has a relationship to financial behavior (Xiao and Porto, 2016), and it also has a direct correlation to the financial position (Rehman et al., 2019). Meanwhile, financial behavior has a 
relationship in evaluating financial position (Totenhagen et al., 2019). In the previous research studies, the research hypotheses made, and it illustrated in Figure 1 with five research hypotheses design.



Figure 1. Hypothesis Test Model

Hypothesis 1: Financial capability influences financial behavior

Hypothesis 2: Income influences financial behavior

Hypothesis 3: Financial capability influences financial position

Hypothesis 4: Income influences financial position

Hypothesis 5: Financial behavior influences the financial position

\section{METHODS}

This research included an experimental study to test the research model, which based on the hypotheses model illustrated in Figure 1. The variables focused on financial capability, income, financial behavior, and financial position. The research survey conducted to 100 youth employees in Central Jakarta who had worked for three years at least. Data from respondents obtained through a quantitative questionnaire whose answers had determined before, the value of " 1 " for very low criteria, and the value of " 5 " for very high standards. The questions were in line with the indicators on each variable, where for financial capability was built by seven signs, five indicators make income, five indicators create financial behavior and eight indicators build the financial position. Data and information from respondents tabulated and processed through the SmartPLS analysis tool; remembered that the hypotheses model contained the variable mediation, and the data were less than 200. The analysis carried out with the Inner and Outer Model test, then test research hypothesis, which based on the model in Figure 1.

\section{RESULTS AND DISCUSSIONS}

Result of Model Test. Data from the distribution of a questionnaire to 100 respondents, which returned to be valid, is a perfect filling as many as 99 respondents. So, there are only 99 data obtained through SmartPLS by testing the model is the Inner and Outer Model test. The first test is through the Inner Model, where it finishes by evaluating the coefficient of determination or $\mathrm{R}^{2}$ and the parameter coefficient of T-Statistics (table 1). Inner Model test 
results from the value of Outer Weight values summarized in Table 3, which explains that the results of all indicators on the latent variable are related well to the value of $t$-statistic is $>3,010$.

Table 1. Outer Weight Values

\begin{tabular}{|c|c|c|c|c|c|}
\hline Instruments & $\begin{array}{c}\text { Original } \\
\text { Sample }(\mathbf{O})\end{array}$ & $\begin{array}{c}\text { Sample } \\
\text { Mean (M) }\end{array}$ & $\begin{array}{l}\text { Standard } \\
\text { Deviation } \\
\text { (STDEV) }\end{array}$ & $\begin{array}{c}\text { T Statistics } \\
\text { (|O/STDEV|) }\end{array}$ & $\begin{array}{c}\mathbf{P} \\
\text { Values }\end{array}$ \\
\hline FB1 <- Financial Behavior & 0,322 & 0,319 & 0,019 & 4,715 & 0,000 \\
\hline FB2 <- Financial Behavior & 0,145 & 0,105 & 0,053 & 4,949 & 0,000 \\
\hline FB3 <- Financial Behavior & 0,162 & 0,159 & 0,008 & 4,506 & 0,000 \\
\hline FB4 <- Financial Behavior & 0,361 & 0,335 & 0,030 & 4,775 & 0,000 \\
\hline FB5 <- Financial Behavior & 0,643 & 0,610 & 0,091 & 7,064 & 0,000 \\
\hline FC1 <- Financial Capability & 0,234 & 0,229 & 0,030 & 7,675 & 0,000 \\
\hline FC2 <- Financial Capability & 0,119 & 0,129 & 0,040 & 3,960 & 0,000 \\
\hline FC3 <- Financial Capability & 0,089 & 0,077 & 0,072 & 3,237 & 0,000 \\
\hline FC4 <- Financial Capability & 0,198 & 0,197 & 0,038 & 5,224 & 0,000 \\
\hline FC5 <- Financial Capability & 0,268 & 0,264 & 0,045 & 5,915 & 0,000 \\
\hline FC6 <- Financial Capability & 0,271 & 0,271 & 0,033 & 8,316 & 0,000 \\
\hline FC7 <- Financial Capability & 0,280 & 0,280 & 0,037 & 7,595 & 0,000 \\
\hline FP1 <- Financial Position & 0,190 & 0,191 & 0,026 & 7,327 & 0,000 \\
\hline FP2 <- Financial Position & 0,159 & 0,155 & 0,033 & 4,839 & 0,000 \\
\hline FP3 <- Financial Position & 0,072 & 0,078 & 0,036 & 3,010 & 0,000 \\
\hline FP4 <- Financial Position & 0,080 & 0,087 & 0,032 & 3,523 & 0,000 \\
\hline FP5 <- Financial Position & 0,185 & 0,185 & 0,035 & 5,248 & 0,000 \\
\hline FP6 <- Financial Position & 0,218 & 0,213 & 0,029 & 7,451 & 0,000 \\
\hline FP7 <- Financial Position & 0,200 & 0,200 & 0,029 & 6,940 & 0,000 \\
\hline FP8 <- Financial Position & 0,250 & 0,242 & 0,030 & 8,336 & 0,000 \\
\hline I1 <- Income & 0,258 & 0,255 & 0,047 & 5,491 & 0,000 \\
\hline I2 <- Income & 0,194 & 0,195 & 0,065 & 3,965 & 0,000 \\
\hline I3 <- Income & 0,260 & 0,259 & 0,065 & 3,986 & 0,000 \\
\hline I4 <- Income & 0,373 & 0,371 & 0,044 & 8,470 & 0,000 \\
\hline I5 <- Income & 0,375 & 0,368 & 0,054 & 6,946 & 0,000 \\
\hline
\end{tabular}

The second test is through the Outer Model test. In contrast, the analysis carried out to all indicators that assessed in all variables, including the Convergent Validity test, the Composite Reliability test, the Average Variance Extracted test, and the Discriminant Validity test. The variables tested are included in financial capability, income, financial behavior, and financial position. In the Convergent Validity test, it tested through an outer loading value with the criteria of passing the test if the measurement of individual reflective is required; it correlates more than 0.30. Furthermore, for Discriminant Validity test is measured based on the value of reliability, which stated to expect the criteria if it has Composite Reliability above 0.7. Whereas the Average Variance Extracted, the test indicated to require the requirements when the AVE value is more significant than 0.5 . The next test is Cronbach's Alpha test, which measured through Discriminant Validity value with the criteria is above 0.7. Inner and Outer model testing carried out in this study, which attached in Table 2 and Table 3, with the results of all tests stated to the requirements. Based on Inner and Outer test results of the model, it can say that the research model is acceptable because it fulfills the requirements of Good of Fit. 
Table 2. Outer Loading Values

\begin{tabular}{|c|c|c|c|c|}
\hline Instruments & $\begin{array}{c}\text { Financial } \\
\text { Capability }\end{array}$ & Income & $\begin{array}{l}\text { Financial } \\
\text { Behavior }\end{array}$ & $\begin{array}{c}\text { Financial } \\
\text { Position }\end{array}$ \\
\hline FB1 & & & 0,601 & \\
\hline FB2 & & & 0,555 & \\
\hline FB3 & & & 0,559 & \\
\hline FB4 & & & 0,506 & \\
\hline FB5 & & & 0,846 & \\
\hline FC1 & 0,758 & & & \\
\hline $\mathrm{FC} 2$ & 0,563 & & & \\
\hline FC3 & 0,545 & & & \\
\hline FC4 & 0,701 & & & \\
\hline FC5 & 0,622 & & & \\
\hline FC6 & 0,807 & & & \\
\hline FC7 & 0,759 & & & \\
\hline FP1 & & & & 0,760 \\
\hline FP2 & & & & 0,728 \\
\hline FP3 & & & & 0,578 \\
\hline FP4 & & & & 0,576 \\
\hline FP5 & & & & 0,729 \\
\hline FP6 & & & & 0,760 \\
\hline FP7 & & & & 0,722 \\
\hline FP8 & & & & 0,826 \\
\hline I1 & & 0,653 & & \\
\hline $\mathrm{I} 2$ & & 0,589 & & \\
\hline I3 & & 0,612 & & \\
\hline I4 & & 0,815 & & \\
\hline I5 & & 0,781 & & \\
\hline
\end{tabular}

Table 3. Value of Reliability and Validity Test

\begin{tabular}{l|c|c|c|c}
\hline \multicolumn{1}{c|}{ Variables } & $\begin{array}{c}\text { Cronbach's } \\
\text { Alpha }\end{array}$ & rho_A & $\begin{array}{c}\text { Composite } \\
\text { Reliability }\end{array}$ & $\begin{array}{c}\text { Average Variance } \\
\text { Extracted (AVE) }\end{array}$ \\
\hline Financial Capability & 0,615 & 0,812 & 0,721 & 0,631 \\
\hline Income & 0,673 & 0,725 & 0,792 & 0,645 \\
\hline Financial Behavior & 0,662 & 0,519 & 0,775 & 0,593 \\
\hline Financial Position & 0,868 & 0,889 & 0,892 & 0,611 \\
\hline
\end{tabular}

Result of Hypothesis Test. After knowing good-of-fit from the Inner and Outer Model test, the study results based on the research model of mediation of financial behavior whose results illustrated in Figure 1. The research results explain that financial capability and income have a good relationship with financial behavior and financial position. It is different from financial behavior, where it has a weak relationship directly or it does not impact to financial position. It explains that financial behavior is not able to be a mediator for financial capability and income in evaluating the financial position.

The following research result is the research hypothesis test, where the test results have summarized in Table 4. The test results found that all the relationships stated to be significant, or it has a positive impact, except for the involvement of financial behavior in financial position. It is clear by comparing T-table value with $\mathrm{T}$-value, where $\mathrm{T}$-value must 
be higher than 1.69. From all the relationships between variables, only the relationship between financial behavior and financial position whose value is below the minimum statistical limit.

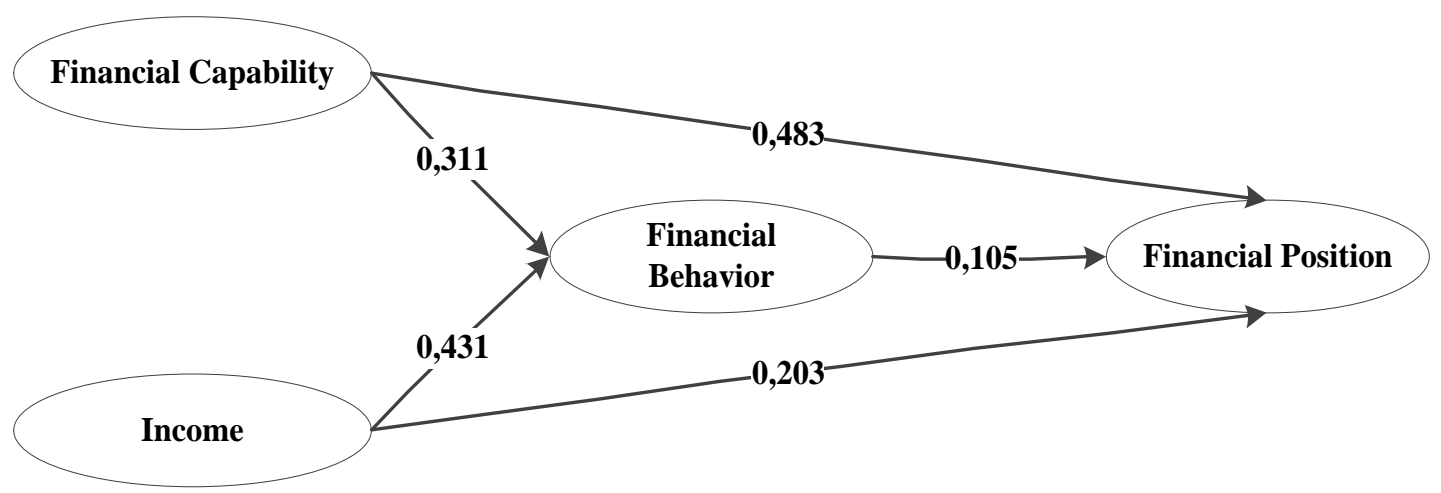

Figure 2. Test of Model Mediation Financial Behavior

Table 4. Test of Hypotheses

\begin{tabular}{l|c|c|c}
\hline \multicolumn{1}{c|}{ Hypotheses } & t-value & Criteria \\
\hline Financial Capability $\rightarrow$ Financial Behavior & H1 & 3,277 & Significant \\
\hline Income $\rightarrow$ Financial Behavior & H2 & 3,684 & Significant \\
\hline Financial Capability $\rightarrow$ Financial Position & H3 & 5,379 & Significant \\
\hline Income $\rightarrow$ Financial Position & H4 & 1,818 & Significant \\
\hline Financial Behavior $\rightarrow$ Financial Position & H5 & 0,766 & Insignificant \\
\hline
\end{tabular}

Impact of Financial Capability and Income to Financial Behavior. Examining the research results is shown in Figure 2; it knows that financial capability has a relationship to financial behavior. It indicated by a correlation value of 0.311 ; this positive relationship, if it increased through the terminated coefficient value, is known to have an impact of $9.6 \%$. It means that the higher the implementation of financial behavior, the better of financial behavior to youth employees. Furthermore, it also knows that the amount of income has a relationship to financial behavior with a correlation value of 0.431 or a positive impact on the financial behavior of $18.6 \%$. It is like financial capability; it seems that the amount of income can influence the increase in understanding of youth employees related to financial behavior. However, when compared to the impact value of the income number owned by youth employees is more significant than financial capability, so that in the priority scale controlling financial behavior is preferred for an understanding of income number, afterward in the implementation of financial capability. It has been stated that financial management which includes planning, management and financial control activities is very important to achieve financial prosperity (Arianti, 2017). Planning activities include activities to plan the allocation of income earned will be used for anything. Management is an activity to regulate or manage finances efficiently while control is an activity to evaluate whether financial management is in accordance with what was planned or budgeted for. Good management of finances certainly affects the financial capabilities they have, so that it seems clear that they can change a person's financial behavior. This is in line with the income they have, where the impact on a person's financial behavior. 
Financial behavior illustrates how individuals behave when faced with financial decisions that must be made. Financial behavior can also be interpreted as a theory based on psychology that seeks to understand how emotion and cognitive storage affect investor behavior. In the midst of today's global economic development, every individual must be a smart consumer to be able to manage his personal finances by building financial literacy that leads to healthy financial behavior. Self-control is a financial behavior that is very useful if it is understood and can be applied in everyday life. Financial behavior studies how humans actually behave in a financial determination, specifically studying how psychology affects financial decisions, companies and financial markets. The two concepts that are clearly described state that financial behavior is an approach that explains how humans invest or deal with finance is influenced by income and financial capability. Financial behavior relates to a person's financial responsibility in terms of financial management. Financial responsibility is a process of managing money and assets that is carried out productively. Money management is the process of controlling and using financial assets. There are several elements that go into effective money management, such as setting a budget and assessing purchases based on need. The main activity in money management is the budgeting process. The budget aims to ensure that individuals can manage financial liabilities in a timely manner using the income received in the same period. This part of the study seems to be in line with previous studies, was it known in earlier studies that financial capability has an impact on positive changes in financial behavior (Wilmarth, 2017). Similarly, the basic income of employees who have a positive effect on the development of financial behavior (Xiao and Porto, 2016). This part of the research novelty perfects the previous studies, and it provides useful information both for youth employees in understanding the amount of income and financial capability, as well as for banks and government in understanding the financial behavior of youth employees in Indonesia. It seems clearly that the essence of the study results explains the impact of financial capability and income on financial behavior changes.

The antecedent of Financial Position. The study results explained, and it found that factors could control financial position are financial capability and the amount of income of youth employees. This result knows from the number of correlation values of financial capability in the financial position of 0.483 . If it increased to become the influence, the value number is $23.3 \%$ of financial capability in financial position. It explains the higher implementation from financial capability, the better achievement of the financial position of youth employees. Besides that, it has known that correlation value from the amount of income of youth employees in financial position is known to be 0.203. If increased to influence, the number of forces is known to be $4.1 \%$, which can emphasize if the higher income of youth employees, the better of financial position. However, when it examined, it appears that financial capability has a more significant impact than the amount of income in financial position. So, it can know that problem facts in evaluating financial position need to prioritize financial capability, and it continued with the amount of income. Financial management is an activity of planning, applying, and controlling the use of funds, raising funds, and sharing profits (Vithessonthi and Kumarasinghe, 2016). Taken together, the three financial decisions are determinants of the level of firm value. So, we need an optimal combination of the three interrelated decisions. Investment decisions need funds, on the other hand funding decisions affect each other with dividend decisions, it appears in the use of internal 
sources of funds that come from profits that are not shared. If person understand how and why accounting exists, how financial statements are used, you will be able to better imagine what is going on, and why accounting information has very important meaning. From the income owned by someone, it should be able to be implemented with better financial behavior, to support the goals of finance, namely a balance between income, expenses, and personal savings.

The attitude of consumerism that has become a habit today makes people less have a culture of saving, for example in terms of investing. There are still many people who do not realize the importance of having financial management in their personal lives because people still think that personal financial investment planning is only done by people who have high incomes. But on the other hand, there are also individuals who have high incomes but do not have an investment plan for their personal finances. Most of the allocation of funds is aimed at several things, namely, investment, savings and consumption. Among these three things, the type of allocation that will provide the most benefit in the future is investment. Investment planning in personal finance is important, because it is a selflearning process to manage finances in the present and in the future. In financial behavior it is conveyed that people need to survive in modern society. This basic knowledge involves knowing and understanding the complex principles of spending, saving and investing. This behavior points to the importance of financial behavior to balance one's financial position in the end. In this study, it is known that there are two important things that can control financial behavior, namely income and financial capability. This part of the study seems to be in line with previous studies where it knows that the antecedent of a financial position can be controlled by two things, which are financial capability (Moreland, 2018) and income of employees (Rehman et al., 2019). The novelty found is a refinement of previous research findings. And these findings provide useful information for stakeholders such as youth employees, banks, and government in understanding the factors that can control the financial position of youth employees concerning their assets. It can analyze the antecedents of financial position sourced from financial behavior and the amount of income.

Model of Financial Position. The findings of subsequent studies based on problem facts known that financial behavior has a relationship to a financial position, with a correlation value of 0.105 . However, if it reviewed deeper, it appears that financial behavior is not able to influence financial position. Remember that the hypothesis test results stated to be insignificant (Table 4), and they not recommended to consider when it is related to financial position. When it examined, it appears that this study is not in line with previous studies, and it tends to argue the previous research (Totenhagen et al., 2019). In which financial behavior is not always able to control financial position, it considers that there are still other factors that can influence them. Financial position is a basic need for everyone to avoid financial problems. Financial difficulties are not only a function of income alone, financial difficulties can also arise if there are errors in financial management such as misuse of credit, and absence of financial planning. Financial literacy, which is gaining more attention in developed countries, has made to realize how important the level of financial awareness. Individuals who have the ability to make correct decisions about finances will not have financial problems in the future and show healthy financial behavior and are able to determine priority needs. Healthy financial behavior is shown by good financial planning, management and control activities. 
Based on the results of previous studies, it known that financial capability and income can influence financial behavior and financial position. The meaning is it seems that it needs a change in research model where financial capability and the amount of income are antecedents from financial behavior and financial position. It seems clear that the position of financial behavior and financial position are aligned; it has explained in previous studies that often examine the similarities of financial behavior and financial position (Handgraaf et al., 2013; Schwartz, 2010; Wilmarth, 2017). Although the two are different, they become the final goals that need to be noticed by youth employees regarding financial management. The implication of this research is aimed specifically at youth employees, who have an income that needs to be regulated as early as possible. In order to become a better behavior in the future, because time is running. Things that need to be instilled by a youth emproyee are the amount of income and financial capability, it is hoped that they will be able to manage their income with financial planning that is in accordance with the budget and implement financial knowledge because they already have financial capability.

\section{CONCLUSIONS}

Based on the research objectives, this study focuses on studying financial behavior, which is influenced by financial capability and income in evaluating the financial position. Where the final goal is to assess the level of financial position of youth employees as part of financial management. The essence of research finding knows that financial capability and income can influence financial behavior directly. Besides, financial capability and income have a positive impact on financial position. However, financial behavior does not affect an increasing financial position. So that financial behavior not recommended as mediation in assessing the relationship of financial capability and income in financial position. This finding certainly has a significant impact on youth employees in evaluating financial management activities, which needs to pay attention to the amount of income and the implementation of financial capability. Also, this research expected to be able to provide information about financial behavior for government and banks in Indonesia so that the policy direction can lead to financial position behavior as measured by the number of assets owned by society. Furthermore, income are antecedents from financial behavior and financial position.

It seems clear that the findings of this study put forward financial behavior, which can be influenced by income and financial capability. Furthermore, income and financial capability can also directly influence financial position. However, the study in this study has limitations, where the number of respondents and the scope of the respondents are limited. In fact, the behavior of a person's finances is very varied and depends on the location of where they are. Furthermore, this research too do not appear to discuss the characteristics of respondents and do not discuss individual behavior in finance, such as financial attitude so that it becomes a further research suggestion. So, the research development of financial behavior expected to be more developed, and it can provide benefits for youth employees related to financial position. 


\section{REFERENCES}

Alamsyah, D. P., Othman, N. A., and Mohammed, H. A. A. (2020). The awareness of environmentally friendly products: The impact of green advertising and green brand image. Management Science Letters, 10, 1961-1968. https://doi.org/10.5267/j.msl.2020.2.017.

Arianti, B. F. (2017). The Influence of Financial Literacy, Financial Behavior and Income on Investment Decision. European Research Studies Journal, 20(3A), 635-648.

Armijo, L. E., Mühlich, L., and Tirone, D. C. (2014). The systemic financial importance of emerging powers. Journal of Policy Modeling, 36(S1), S67-S88. https://doi.org/10.1016/j.jpolmod.2013.10.009.

Bohl, M. T., Klein, A. C., and Siklos, P. L. (2014). Short-selling bans and institutional investors' herding behaviour: EVIDENCE from the global financial crisis. International Review of Financial Analysis, 33, 262-269. https://doi.org/10.1016/j.irfa.2014.03.004.

Bretscher, L., Julliard, C., and Rosa, C. (2016). Human capital and international portfolio diversification: A reappraisal. Journal of International Economics, 99, S78-S96. https://doi.org/10.1016/j.jinteco.2015.12.007.

Chen, M. H., and Lin, C. P. (2015). Understanding corporate philanthropy in the hospitality industry. International Journal of Hospitality Management, 48, 150-160. https://doi.org/10.1016/j.ijhm.2015.04.001.

Danilov, A., Biemann, T., Kring, T., and Sliwka, D. (2013). The dark side of team incentives: Experimental evidence on advice quality from financial service professionals. Journal of Economic Behavior and Organization, 93, 266-272. https://doi.org/10.1016/j.jebo.2013.03.012.

Delis, M. D., and Mylonidis, N. (2015). Trust, happiness, and households' financial decisions. Journal of Financial Stability, 20, 82-92. https://doi.org/10.1016/j.jfs.2015.08.002.

Díaz Caro, C., and Crespo Cebada, E. (2016). Taxation of capital gains and Lock-in effect in the Spanish Dual Income Tax. European Journal of Management and Business Economics, 25(1), 15-21. https://doi.org/10.1016/j.redee.2015.11.001.

Dwiastanti, A. (2017). Analysis of financial knowledge and financial attitude on locus of control and financial management behavior. Management and Business Review, 1(1), $1-8$.

El-Khatib, R., Fogel, K., and Jandik, T. (2015). CEO network centrality and merger performance. Journal of Financial Economics, 116(2), 349-382. https://doi.org/10.1016/j.jfineco.2015.01.001.

Fauceglia, D. (2014). Credit constraints and firm imports of capital goods: Evidence from middle- and low-income countries. International Economics, 140, 1-18. https://doi.org/10.1016/j.inteco.2014.07.002.

Gaganis, C., and Pasiouras, F. (2013). Financial supervision regimes and bank efficiency: International evidence. Journal of Banking and Finance, 37(12), 5463-5475. https://doi.org/10.1016/j.jbankfin.2013.04.026.

Gelman, M., Jochem, A., Reitz, S., and Taylor, M. P. (2015). Real financial market exchange rates and capital flows. Journal of International Money and Finance, 54, 50-69. https://doi.org/10.1016/j.jimonfin.2015.02.004. 
Georgescu, D., and Mates, D. (2017). Influencing The Performance and Financial Position as Reported in The Annual Financial Statements Using Creative Methods. North Economic Review, I(1), 104-108.

Godlewski, C. J. (2014). Bank loans and borrower value during the global financial crisis: Empirical evidence from France. Journal of International Financial Markets, Institutions and Money, 28(1), 100-130. https://doi.org/10.1016/j.intfin.2013.10.009.

Goedde-Menke, M., Langer, T., and Pfingsten, A. (2014). Impact of the financial crisis on bank run risk - Danger of the days after. Journal of Banking and Finance, 40(1), 522533. https://doi.org/10.1016/j.jbankfin.2013.11.028.

Haeussler, C., and Sauermann, H. (2013). Credit where credit is due? the impact of project contributions and social factors on authorship and inventorship. Research Policy, 42(3), 688-703. https://doi.org/10.1016/j.respol.2012.09.009.

Handgraaf, M. J. J., Van Lidth de Jeude, M. A., and Appelt, K. C. (2013). Public praise vs. private pay: Effects of rewards on energy conservation in the workplace. Ecological Economics, 86, 86-92. https://doi.org/10.1016/j.ecolecon.2012.11.008.

Hariyanto, O. I. B., and Alamsyah, D. P. (2019). The Relationship Of Environmental Knowledge And Green Purchase Intention. International Journal of Engineering and Advanced Technology, 8(5), 142-144. https://doi.org/10.35940/ijeat.E1020.0585C19.

Henager, R., and Cude, B. J. (2016). Financial Literacy and Long- and Short-Term Financial Behavior in Different Age Groups. Journal of Financial Counseling and Planning, 27(1), 3-19.

Holmes, M. J., and Maghrebi, N. (2016). Financial market impact on the real economy: An assessment of asymmetries and volatility linkages between the stock market and unemployment rate. Journal of Economic Asymmetries, 13, 1-7. https://doi.org/10.1016/j.jeca.2015.10.003.

Indris, S., and Primiana, I. (2015). Internal And External Environment Analysis On The Performance Of Small And Medium Industries Smes In Indonesia. International Journal of Scientific \& Technology Research, 4(4), 188-196.

Kadoya, Y., and Khan, M. (2017). Explaining Financial Literacy in Japan: New Evidence Using Financial Knowledge, Behavior, and Attitude. SSRN Electronic Journal, February. https://doi.org/10.2139/ssrn.3067799.

Kenç, T., Erdem, F. P., and Ünalmış, İ. (2016). Resilience of emerging market economies to global financial conditions. Central Bank Review, 16(1), 1-6. https://doi.org/10.1016/j.cbrev.2016.03.002.

Killip, G. (2013). Products, practices and processes: Exploring the innovation potential for low-carbon housing refurbishment among small and medium-sized enterprises (SMEs) in the UK construction industry. Energy Policy, 62, 522-530. https://doi.org/10.1016/j.enpol.2013.06.024.

Košak, M., Li, S., Lončarski, I., and Marinč, M. (2015). Quality of bank capital and bank lending behavior during the global financial crisis. International Review of Financial Analysis, 37, 168-183. https://doi.org/10.1016/j.irfa.2014.11.008.

Laforet, S. (2007). British grocers' brand extension in financial services. Journal of Product and Brand Management, 16(2), 82-97. https://doi.org/10.1108/10610420710739964.

Lee, C. C., Lin, C. W., and Zeng, J. H. (2016). Financial liberalization, insurance market, and the likelihood of financial crises. Journal of International Money and Finance, 62, 25-51. https://doi.org/10.1016/j.jimonfin.2015.12.002. 
Levis, M., Meoli, M., and Migliorati, K. (2014). The rise of UK Seasoned Equity Offerings (SEOs) fees during the financial crisis: The role of institutional shareholders and underwriters. Journal of Banking and Finance, 48, 13-28. https://doi.org/10.1016/j.jbankfin.2014.04.034.

Mirvis, P. H., Hurley, S. T., and MacArthur, A. (2014). Transforming executives into corporate diplomats: The power of global pro bono service. Organizational Dynamics, 43(3), 235-245. https://doi.org/10.1016/j.orgdyn.2014.08.010.

Moradi, Z. S., Mirzaeenejad, M., and Geraeenejad, G. (2016). Effect of Bank-Based or Market-Based Financial Systems on Income Distribution in Selected Countries. Procedia Economics and Finance, 36(16), 510-521. https://doi.org/10.1016/s22125671(16)30067-3.

Moreland, K. A. (2018). Seeking financial advice and other desirable financial behaviors. Journal of Financial Counseling and Planning, 29(2), 198-207. https://doi.org/10.1891/1052-3073.29.2.198.

Newberry, S. (2015). Public sector reforms and sovereign debt management: Capital market development as strategy? Critical Perspectives on Accounting, 27, 101-117. https://doi.org/10.1016/j.cpa.2013.10.006.

Norden, L., Silva Buston, C., and Wagner, W. (2014). Financial innovation and bank behavior: Evidence from credit markets. Journal of Economic Dynamics and Control, 43, 130-145. https://doi.org/10.1016/j.jedc.2014.01.015.

Pedersen, E. R. G., and Sudzina, F. (2012). Which firms use measures?: Internal and external factors shaping the adoption of performance measurement systems in Danish firms. International Journal of Operations and Production Management, 32(1), 4-27. https://doi.org/10.1108/01443571211195718.

Pi, S.-M., Liao, H.-L., and Chen, H.-M. (2012). Factors That Affect Consumers' Trust and Continuous Adoption of Online Financial Services. International Journal of Business and Management, 7(9), 108-119. https://doi.org/10.5539/ijbm.v7n9p108.

Pintea, M.-O., Stanca, L., Achim, S.-A., and Pop, I. (2014). Is there a Connection among Environmental and Financial Performance of a Company in Developing Countries? Evidence from Romania. Procedia Economics and Finance, 15(14), 822-829. https://doi.org/10.1016/s2212-5671(14)00527-9.

Rai, K., Dua, S., and Yadav, M. (2019). Association of Financial Attitude, Financial Behaviour and Financial Knowledge Towards Financial Literacy: A Structural Equation Modeling Approach. FIIB Business Review, 8(1), 51-60. https://doi.org/10.1177/2319714519826651.

Ramanathan, R., Ramanathan, U., and Zhang, Y. (2016). Linking operations, marketing and environmental capabilities and diversification to hotel performance: A data envelopment analysis approach. International Journal of Production Economics, 176, 111-122. https://doi.org/10.1016/j.ijpe.2016.03.010.

Rehman, K. U., Akhtar, H., and Shah, S. Z. A. (2019). Framing Effect and Financial Wellbeing: Role of Investment Behaviors as Mediator. Review of Economics and Development Studies, 5(2), 343-354. https://doi.org/10.26710/reads.v5i2.555.

Sawarjuwono, T. (2003). Intellectual Capital: Perlakuan, Pengukuran Dan Pelaporan (Sebuah Library Research). Jurnal Akuntansi Dan Keuangan, 5(1), 35-57. https://doi.org/10.9744/jak.5.1.pp.35-57.

Sawitri, N. N., and Astuty, P. (2018). Market anomalies and effect on returns. European 
Research Studies Journal, 21(2), 630-649. https://doi.org/10.35808/ersj/1029.

Sawitri, Ni Nyoman. (2019). FDPM after the global price crisis in the coal industry. International Journal of Monetary Economics and Finance, 12(1), 59-74. https://doi.org/10.1504/IJMEF.2019.098699.

Sawitri, Ni Nyoman, Ermayanti, D., Farida, U., Junus, D., Baharuddin, Hasmin, Yusriadi, Rachman, E., Jumra, and Vikaliana, R. (2019). Human Resources Competency, the Use of Information Technology and Internal Accounting Control on Time Procurement of Financial Reporting. Journal of Physics: Conference Series, 1175(1). https://doi.org/10.1088/1742-6596/1175/1/012263.

Schwartz, H. (2010). Does Akerlof and Shiller's Animal Spirits provide a helpful new approach for macroeconomics? Journal of Socio-Economics, 39(2), 150-154. https://doi.org/10.1016/j.socec.2010.02.018.

Shen, C. H., Wu, M. W., Chen, T. H., and Fang, H. (2016). To engage or not to engage in corporate social responsibility: Empirical evidence from global banking sector. Economic Modelling, 55, 207-225. https://doi.org/10.1016/j.econmod.2016.02.007.

Shivam Dube, V., and Kumar Asthana, P. (2017). A Comparative Study on Financial Literacy of Uttar Pradesh with Central Zone States in India. Journal of Business and Management, 19(10), 22-27. https://doi.org/10.9790/487X-1910032227.

Singal, M. (2014). The business case for diversity management in the hospitality industry. International Journal of Hospitality Management, 40, 10-19. https://doi.org/10.1016/j.ijhm.2014.02.009.

Sydler, R., Haefliger, S., and Pruksa, R. (2014). Measuring intellectual capital with financial figures: Can we predict firm profitability? European Management Journal, 32(2), 244-259. https://doi.org/10.1016/j.emj.2013.01.008.

Szendrey, J., and Fiala, L. (2018). "I think I can get ahead!" perceived economic mobility, income, and financial behaviors of young adults. Journal of Financial Counseling and Planning, 29(2), 290-303. https://doi.org/10.1891/1052-3073.29.2.290.

Totenhagen, C. J., Wilmarth, M. J., Serido, J., Curran, M. A., and Shim, S. (2019). Pathways from Financial Knowledge to Relationship Satisfaction: The Roles of Financial Behaviors, Perceived Shared Financial Values with the Romantic Partner, and Debt. Journal of Family and Economic Issues, 40(3), 423-437. https://doi.org/10.1007/s10834-019-09611-9.

Vithessonthi, C., and Kumarasinghe, S. (2016). Financial development, international trade integration, and stock market integration: Evidence from Asia. Journal of Multinational Financial Management, 35, 79-92. https://doi.org/10.1016/j.mulfin.2016.03.001.

Wang, Y. K. M., Chung, C. C., and Lim, D. S. K. (2015). The drivers of international corporate entrepreneurship: CEO incentive and CEO monitoring mechanisms. $\begin{array}{llll}\text { Journal of } \text { World } & \text { 742-753. }\end{array}$ https://doi.org/10.1016/j.jwb.2015.02.002.

Wilmarth, M. J. (2017). Financial Behaviors of Military Households: The Role of Financial Literacy and Financial Education. Consumer Interests Annual, 63(1), 1-2.

Wong, R., Ng, P., Bonino, J., Gonzaga, A. M., and Mieczkowski, A. E. (2018). Financial Attitudes and Behaviors of Internal Medicine and Internal Medicine-Pediatrics Residents. Journal of Graduate Medical Education, 10(6), 639-645. https://doi.org/10.4300/JGME-D-18-00015.1. 
Xiao, J. J., and Porto, N. (2016). Financial Education and Financial Satisfaction: Financial Literacy, Behavior, and Capability as Mediators. International Journal of Bank Marketing. https://doi.org/10.1108/IJBM-01-2016-0009.

Yusoff, W. F. W., and Adamu, M. S. (2016). The relationship between corporate social responsibility and financial performance: Evidence from Malaysia. In International Business Management (Vol. 10, Issue 4, pp. 345-351). https://doi.org/10.3923/ibm.2016.345.351. 